\title{
Dr June Caridad Pagaduan-Lopez
}

\author{
June 5, 1951 - November 20, 2021
}

Aurora Corazon A. Parong ${ }^{1}$

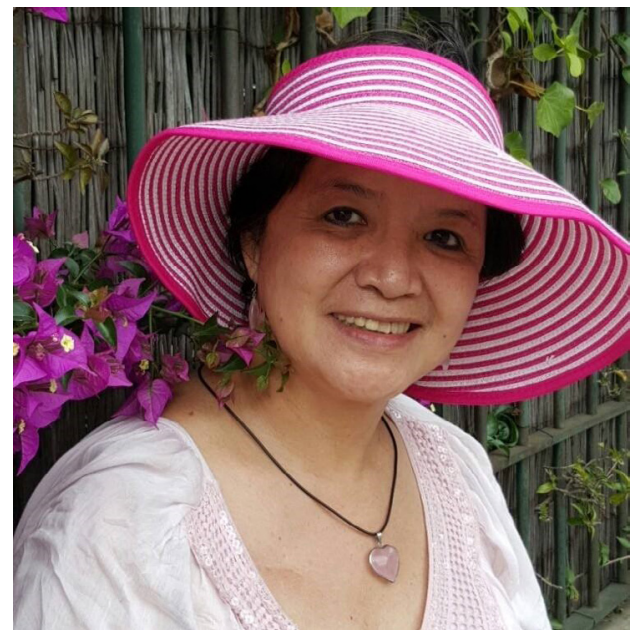

Picture of Fune selected by the family

With great sadness, we mourn the passing of Dr June Caridad Pagaduan Lopez, a dear friend and colleague in the healing profession, on November 20, 2021. She was an inspiration who gave hope to many, a powerhouse in the anti-torture movement and a champion for justice.

She graduated from the University of the Philippines College of Medicine when torture, killings and other grave human rights viola-

1) M.D. Vice-Chairperson, Amnesty International Philippines. Co-Chairperson, Philippine Coalition for the International Criminal Court (PCICC). Former Board Member, Human Rights Victims' Claims Board (HRVCB) tions were widespread during the dictatorship of Ferdinand E. Marcos. She specialised in psychiatry and used her expertise in rendering services to survivors of torture during martial law in the 1980s. She later developed a bio-psychosocial approach in caring for those who suffered physical and mental torture and indignities at the hands of government authorities when they were arbitrarily arrested and detained. She established the Philippine Action Concerning Torture of the Medical Action Group (MAG) using a broader approach to consider factors beyond the dominant biomedical approach to disease, health and well-being. She gave hope to victims of torture and their families during the dark years in the Philippines.

She linked with other health professionals from different parts of the world then became one of the founders of the IRCT (International Rehabilitation Center for Torture Victims) based in Denmark. As MAG considered the distinct characteristics of those tortured and Filipino psychology, Doc June ensured that lessons were learned from other health professionals in other countries helping victims and survivors of organised violence. She trained others in torture prevention and rehabilitation. She cared for survivors of torture and trained some of them to become healers to overcome traumatic experiences and be empowered to help others. Her broad network opened doors 
for some of the health professionals in the Philippines to exchange experiences with others and train outside the country on the rehabilitation of torture victims.

Doc June consistently wrote about the importance of medical ethics when she found the complicity of doctors in torture in the Philippines. She strongly spoke about the need to emphasise the health profession's ethical principles and social responsibilities to render services to the marginalised and unjustly treated. June inspired health professionals to go to the rural areas to render services to the underserved victims of torture, relatives of victims of killings and severe injustices and at the same time demanded the obligations of the government to protect doctors and other health workers who respond to the call of service to anyone regardless of political persuasion, beliefs and social status. She went beyond the usual health services and highlighted the critical role of doctors and health professions in the efforts to seek justice and intensely worked for the development of the medico-legal system in the Philippines so that doctors and scientists could provide testimonies that may be used in the courts to make torturers or other violators of human rights accountable. She strongly advocated for the Istanbul Protocol as the tool to document and report torture and other cruel and inhuman treatment of persons deprived of liberty.

She also went to communities affected by tragic disasters and armed conflict and helped people, especially children and women victims of violence and disasters suffering from collective trauma. She organised the Balik Kalipay Center for Psychosocial Response and mentored students and doctors to broaden their outlook about the health professionals' role in conflict and disaster-affected communities.

June was passionate about her work and exhibited great courage to articulate her views for the common good. When she served as an expert of the United Nations Subcommittee for the Prevention of Torture (SPT) for eight years (2012-2020), she gave her best. One of her colleagues from the SPT said: "June is a serious loss to the cause that she lived for, for almost 50 years - defending human rights and democracy and in particular, the fight against torture and for the rights of persons subjected to torture...She was very present and emphatic when speaking to inmates and others deprived of liberty, conveying respect and eagerness to communicate their experiences and make a difference in their lives. She was correct but at the same time direct and clear when speaking with authorities and managed to combine formal correctness with a strong sense, sometimes of indignation, but never to lift her voice, communicating that this cannot happen this way and must be altered as a matter of urgency." Her colleague at SPT went on to say, "You communicated your message in such a calm, mild and concentrated way, and at the same time in a strongly engaged way; and I know of no other person who combines these so well."

After her outstanding stint at SPT, she joined the Interim National Preventive Mechanism against Torture as Vice-Chair, to monitor prisons and other places of detention in the Philippines. She was also a member of the Board of the Medical Action group

A few years ago, she again put her brains and heart into a project on mental health which led to the enactment of a Mental Health Act in the Philippines in 2018. Even when she faced health challenges two months ago, she courageously delivered a lecture on the Mental Health Act from her hospital room.

Dr Lopez is a multi-awarded healer and human rights advocate. In 1989, Dr Lopez received The Outstanding Women in Nation's Service (TOWNS) award for psychiatry in the Philippines. In 1992, she was given the 
Lisl and Leo Eitinger Human Rights Award in Oslo, besides public recognising her work inside the Philippines.

Recently, her pioneering article on "Doctors at Risk", published in the Torture Journal in 1996, was recognised as one of the most important papers written on torture during the last 30 years. The article dealt with doctors' participation in torture, what they know about torture, the risks they face when reporting torture, and the risks of treating torture survivors. These issues are continuing challenges in the world today.

Doc June will be remembered as a happy person, a good friend who can be a shoulder to cry on, a doctor who brings light and human rights activist. One of her patients wrote about her when she passed on: "I think a good psychiatrist gives you hope, but a great psychiatrist tells you why you can keep hoping, and hopes along with you". June is survived by her daughters Kay and Krissy, a son Kim, a granddaughter Elle, sisters and in-laws.

Thank you, Dr June Caridad Lopez, for a life well lived and well shared for the common good in the Philippines and other parts of the world. You will always be an inspiration. We will keep up the spirit and continue the excellent work against torture for human rights and a better world. 